\title{
SOME NOTES ON THE POSSIBILITY OF AN "ISLAMIC ECONOMY" A CASE STUDY
}

\author{
ŞENNUR ÖZDEMIR
}

\begin{abstract}
This article is composed of a short discussion on the possibility of an Islamic Economy. In doing so, it addresses not only conceptual/theoretical aspects (on the base of Weberian Protestant Ethic thesis) related to this field but also its socio-economic historical dimensions that contrasts with the incompatibility thesis referring to the radical changes experienced with the end of colonization period in Islamic countries (and Asiatic non-Western ones as well) as well as slow changes appearing simultaneously in the nature of the so-called Islamic Economy. In this context, some data about MÜSİAD is specifically be depended on. In conclusion, in contrast to the conventional understanding, the study shows that the idea of an Islamic Economy -in its compatibility with modern conditions and systems- has a base to claim for not only in theory but also in reality.
\end{abstract}

\section{KEYWORDS}

Protestant Ethic Thesis, Muslim entrepreneurship, MÜSİAD, Islamic Economy 


\section{An Introductory Discussion}

The general radical crisis of the international system, and the crisis of capitalist modes of production in particular, leads us to think about the possibility and/or presence of multiple/plural modernities ${ }^{1}$ implying even a possibility of a new civilizational synthesis: ${ }^{2}$ Huntington's theory of the clash of civilizations ${ }^{3}$ serves this argument in many respects. It implies that we are passing through a transitory process that will probably result in a civilizational turn.

The dichotomic East/West distinction does not only depend on Islam as a culture and civilisation, but on the Eastern world as a whole. The unique development that East Asian countries have experienced is also relevant here. The question whether capitalism on the base of strong communal rules and weak individuality in the sense of seeking rationally one's own self-interest is possible has gained importance due to the success of these alternative sociocultural settings in the economic realm in competition with Western markets. Creating alternative and successful socio-economic organisations played a positive role in legitimising some peculiarities of the eastern culture that was attributed as an obstacle for a culturally and economically developed society. For instance, the idea that "a high degree of state intervention" is necessarily "incompatible with successful capitalist development" has been falsified. ${ }^{4}$ Although a deep investigation on this specific issue cannot be included in this study, it can be said that the idea of multiple modernizations also works for East Asian cases as well.

\footnotetext{
${ }^{1}$ See, Nilüfer Göle, İslam ve Modernlik Üzerine Melez Desenler. İstanbul: Metis, 2000 and Mike Featherstone, Global Culture: An Introduction. Global Culture, M. Featherstone, (ed.) Sage. 1990.

${ }^{2}$ Şennur Özdemir, "Uluslararasıllkta Kaos, Bir Medeniyet Dönüşümü ve İslami (F)aktör: Türkiye'de MÜSİAD Örneği," Uluslararası İlişkiler, 1/3, (Spring 2004).

${ }^{3}$ See, Samuel P. Huntington, "The Clash of Civilizations?" Foreign Affairs, (Summer 1993).

${ }^{4}$ Still, what was observed for these cases was "The values of individual autonomy are undermining East Asian communalism and are likely to continue doing so" Peter L. Berger, The Capitalist Revolution, New York: Basic Books, 1986, pp. 158, 170.
} 
According to this idea, different cultural settings will be experiencing modernization differently in terms of their own cultural specifisities although the homogenizing effects of modernization such as individualization, rationalization and therefore, internalization and (re)institutionalization of ethical codes- will also be at work, as will be demonstrated in this study for the case of MÜSİAD. Changing conditions and mechanisms of the world's economic system with its flexible and network-centred forms are the factors creating an alternative Islamic agenda possible as part of the world economic community. Surely, this was also due to the growing diversification and liberalization in the markets of Muslim countries themselves.

Islamic religion and culture, being declared as the opposite of Western civilization, has a distinct place in this regard: Islamic civilization, depending on a large Muslim population worldwide, which was excluded from the world economic system as such and declared as the opposite 'other' of the West once, ${ }^{5}$ will at least be expected to be an equal actor in this transitory process -if not even as an advantageous one. ${ }^{6}$ In this context, this study will focus on religiocultural differences of Islamic economy over a fieldwork on MÜSİAD (a businessmen organization with an Islamic emphasis) in Turkey. ${ }^{7}$

5In his 'Orientalism' Edward Said decoded throughoutly this negatively 'orientalizing' nature of western science. And it can be accepted as a turning point in studying Eastern world in specific and the 'others' of the West in general more objectively. Orientalism, New York: Random House, 1975.

${ }^{6} \mathrm{See}$, Özdemir, Uluslararasillkta Kaos, for a discussion supporting Islam's advantageous positioning in this process.

${ }^{7}$ See, Şennur Özdemir, Religious and Socio-Economic Transformation of Turkey: The Case of the MÜSİAD. Unpublished Doctoral Thesis. Ankara: METU, 2001. Indeed, it is known that beyond cultural/religious differences more firms develop network alternatives to conventional markets and hierarcies in the Western world under conditions of the global restructuring of the world: See, Paul DiMaggio, "Culture and Economy," The Handbook of Economic Sociology, N. J. Smelser and R. Swedberg, (eds) Princeton, New Jersey, New York: Princeton University Press, Russel Sage Foundation, 1994, p. 39. 
I argue in this study that the Islamic case is not an exception to this generalization -on the contrary to the conventional perspective that Islamic/Eastern world cannot even be imagined as a dynamic and historically changing socio-economic and cultural whole. As known, until very recently the famous thesis that Islam and modern democratic forms of Western civilisation including rational capitalism are incompatible was given direction to studies on Islam. Can we accept such causality as a fact? This study argues that the answer will be a firm "yes", only if one takes this determination as a historically and socio-economically defined formula, yet at the same time taking this formula as a timeless absolute determination the answer of this question will certainly be negative. To support this idea we can even refer to the neo-Weberian literature which rejects the idea that Islamic culture is inherently in opposition to the capitalist culture. For example, Gellner ${ }^{8}$ tried to show that Islam could be compatible in its offical version and can perfectly be reformed. Swedberg 9 emphasized some points, such as Islamic commercial law that was considered by Weber as "secular and innovative and played a progressive role in the legal development of capitalism...several of which were taken over by the west. What stopped this innovative spirit from further developing and spreading...is that it lacked official protection." Another point Swedberg ${ }^{10}$ emphasized is that there was a dimension of asceticisim in Islam in terms of some regular religious practices such as praying five times a day, according to Weber. ${ }^{11}$

${ }^{8}$ Ernest Gellner, Muslim Society. Cambridge: Cambridge University Press, 1981.

${ }^{9}$ Richard Swedberg, Max Weber and the Idea of Economic Sociology, Princeton, New Jersey: Princeton University Press. 1998, p. 93.

${ }^{10}$ Ibid., p. 143.

${ }^{11}$ Bernard Lewis, too, argued that the problem of the backwardness of Islamic societies should be investigated as a part of larger socio-economic phenomenon rather than as merely a religious one. "The charge that the Islamic religion is innately hostile to economic development is difficult to sustain; the social and cultural causes of economic backwardness in Muslim countries must be sought in a complex of factors, of which historic Islam is a part and, to some extent, an expression. There is nothing in Islamic doctrine to oppose economic progress." Islam in History: Ideas, People, and Events in the Middle East, Chicago: Open Court. 1993, p. 347. 
Therefore, it was largely accepted that the fundamental problem with Eastern Islamic cultures was patrimonialism as the dominant cultural characteristic of the East which was considered as an obstacle both by Weber and Marx for a stratified hierarchical organizaiton of modern capitalism. Indeed, it was patrimonialism ${ }^{12}$ in the last analysis, rather than Islam as a religion, that was declared as the main obstacle for the capitalist development of these countries by both Weberian and Marxist analysis as Turner ${ }^{13}$ underlines. The most typical form of traditional authority in Weber's ${ }^{14}$ analysis is patrimonialism, and that is also the reason why he related what he called "traditional" in its ideal typical sense to eastern societies. The typical characteristics of patrimonial order, Weber noted, was an absolute submission to the authority -of the King, father, elderly people, religious leader, ${ }^{15}$ master, husband and so on, on the contrary to the autonomous individuals of the hierarchical organisation of Western societies.

Indeed, Islamic thinkers were also agreed with this idea by pointing out the central place political processes and state itself took. Ülgener may be considered as the only example, who searched sincerely what was lacked in Islam accoding to the emergence of modern capitalism within the Weberian formula. Classical and contemporary social scientists all put an emphasis on the determinant

${ }^{12}$ See, for instance, Sami Zubaida, "Economic and Political Activism in Islam," Economy and Society, 1972, p. 326; Metin Heper, Bürokratik Yönetim Geleneği, Ankara: ODTÜ İdari Ilimler Fak.1974; Halil İnalcık, Studies in Ottoman Social and Economic History. London: Variorum Reprints.1985; Çağlar Keyder, State and Class in Turkey, London\&New York: Verso. 1987; Şerif Mardin, Türk Modernleşmesi, İstanbul: İletişim.1991; and Ayşe Buğra, Devlet ve İşadamları, İstanbul: İletişim. 1995.

${ }^{13}$ See, Bryan Turner, Weber and Islam: A Critical Study, London, Boston: Routledge, 1974, p. 15.

${ }^{14}$ See, Max Weber, Sosyoloji Yazılarl, İstanbul: Hurriyet Vakfı Yayınları, 1987, p. 253.

${ }^{15}$ Sabri F. Ülgener have examined how this submission has become a mass phenomenon in Islamic history through tarikat and tassavvuf organizations of Anatolian Islam. 1981. Dünü ve Bugünü ile Zihniyet ve Din: Islam, Tasavvuf ve Çözülme Devri İktisat Ahlakı, İstanbul: Der Yayınları. 
role the patrimonial, centralized state played historically and currently as well. Islamic history, with its origin accompanied by a strong state tradition -especially in the Turkish case- or with its small communities, has been considered as a case far away from being a prerequisite for the emergence of an individual-base free market society. As discussed later, Weber provided us with a long repertoire of reasons explaining this connection. However, what Weber and others said was historically bound explanations, and, as all of the classical thinkers underlined, we at least have the duty to refer to actual historical facts by updating what they mean and imply under the current circumstances. The issue refers to the actual developments in the Islamic world, liberal policies in both political and economic spheres experienced in many of the Islamic countries brought about new conceptions such as Islamic economy and Islamic banking since the 1980s. The development, called 'Islamic economy' has become a central issue for academic and political circles and for the media. Even if Islam, at least indirectly, was already a part of the fundamental circles, it has become an issue as an integral part of the contemporary developments in Islamic countries rather than as a reactionary political opposition. That is how a new agenda for Islam has emerged since then, and the present study is a production deriving from this new agenda. Under these changing conditions it considers that economic activities necessarily embedded not only in sociopolitical but also in the cultural realm, including religious institutions and values.

In this context, the importance of MÜSİAD is threefold. First is the role it plays in the process of "inventing" a renewed/rationalised Islamic ethic; second is the specific role it plays to transform the traditional economic mentality that is compatible with rational capitalism and supports the needs of the capitalist organisation of Turkish society; and thirdly, it plays a crucial role as simply a role model by being a relatively elite section of the Islamic community trying the new forms and principles of the renewed ethical and aesthetic Islamic conduct.

What made such an ethical-aesthetic transformation possible, even if there are important socio-cultural differences derived from religious doctrines, namely Islam and protestantism as a transformed 
form of Christianity that is accepted as an irrational base for capitalism, ${ }^{16}$ are issues of historical change, though it is very slow due to their in-depth historical/cultural quality. An increase in horizontal international relations between the capitalist world (mainly Christian) and the non-western ones, including Islamic countries at the end of the colonization period, has largely helped to emerge radical changes in terms of the above mentioned transformation. Such change is responsible to create a proactive agenda for those countries which were reactive and passively colonized since capitalism has began a hegomonic power on a worldwide level. In the way towards the articulation and/or compatibility of Islam and democratic-rational capitalism there are intellectual and socio-economic changes in both cultural settings. Although resistance within a cultural context to an extent is natural in front of a sudden influence of another culture and/or civilisation, long-term interaction will always result in a change even in the most resisting areas of this culture. Yet, to add here that an interaction will never result in a one-sided influence from one cultural context to another in a way that the dominant one determines the other entirely without being affected by the other. Indeed, this is a story of the transformation of other cultures and the process of being transformed as a result of this interaction. This idea will originate from our framework to understand the relationship between modern capitalism and Islam. In my study on MÜSİAD, the relationship between capitalism and Protestant ethic have been overviewed again for the specific purpose of the Turkish case, to understand such deeply rooted changes: MÜSİAD, as a case is a very operational one scientifically, exemplifying what the dynamics of the articulation of cultural and material aspects of modern capitalism in historically and culturally different contexts are in the first place. In this study, MÜSİAD represents an organizational and managerial 'model' based on cooperation, solidarity and partnership as a new structure- a synthesis emerging as a result of blending of rational processes by "autonomous entrepreneurs" in their relation to the traditional/informal forms and values of solidarity.

\footnotetext{
${ }^{16}$ See, Max Weber, The Protestant Ethic and Spirit of Capitalism, London,
} New York: Routledge. 1992. 


\section{A Discussion around the MÜSİAD}

There are not so many studies focused specifically on the relationship between Islam and economy in Turkey, mainly because of the fact that Islam, as part of the traditional culture, is not considered as crucial in its effects on socio-economic development of the country by mainstream social scientific understanding. According to this, Islam would only serve to play and strenghten traditional roles in all aspects of socio-economic and cultural-ideological fields. Therefore, it could only be a negative agent in the Turkish social science studies, if one considered it as a sociological factor to a certain degree. The theoretical problem with the most recent studies that focus on specifically the issue of Islamic economy in the Turkish context is either their reduction of "the rational" as a multidimensional concept to the strategic aspects of the term as framing the assumptions of rational economy in their absolute and ideal meanings ${ }^{17}$.

It is mainly because of the fact that they considered Islamic religion in the economic sphere as a part of a mere rational reasoning by making religion as simply a "tool" for the economic success. Therefore, what is meaningful in terms of its Islamic quality is its being a powerful Islamic subeconomy, and the Islamic dimension of its identity is nothing, but a myth in Kuran's analysis: The connection between Islamic religion and Islamic banking is, therefore, "imaginary" in his understanding ${ }^{18}$. The significance of what is called as Islamic economy, according to Kuran, caused by its functional importance in the contemporary economic conditions as an "economic instrument" only, one is psychological - "guilt relief"- and

${ }^{17}$ See, Timur Kuran, "Islam and Underdevelopment: An Old Puzzle Revisited," Journal of Institutional and Theoretical Economics 153. (1997); and Timur Kuran, "The Genesis of Islamic Economics: A Chapter in the Politics of Muslim Identity," Social Research 64/2, 1997; or to a mere strategic effects as a form within the political economy approach, see Ayşe Buğra, "Class, Culture, and State: An Analysis of Interest Representation By Two Turkish Business Association," International Journal of Middle East Studies 30, (1998) and Ayşe Buğra, Islam in Economic Organizations, Friedrich Ebert Stiftung, İstanbul, 1999.

${ }^{18} \mathrm{See}$, Islam and Underdevelopment p.73; and see his The Genesis, 1997. 
the other one is structural -"creating networks"-19 rather than its Islamic quality. Note here that the meaning of Islamic economy as an attempt has also been reducing to its political implications by pointing out that the idea of an Islamic economy as an alternative economic framework to the western capitalism is illusory: 20

What is more interesting in this context that Kuran considered the diffrences and conflicts between Islamic thinkers about the fundamental issues of modern economy as an evidence proving why the idea of İslamic economy is not realistic. As for Buğra's ${ }^{21}$ analysis, there emerged a group of successful Muslim businessmen in Islamic countries because of their "strategical fit" to the global economy in the very same manner with those East Asian economies. This does not mean that these approaches are not analytically useful, the problem lies in their perception of religion as merely an "instrument" for its socio-economic functions.

On the contrary to this conventional positivistic paradigm, this study rejects the idea that Islam was the main obstacle for the capitalist development of the Turkish economy by depending on detailed historical data. To give an example, it was long before the foundation of the new republic that there was a flexible religious attitude regarding practices of interest that were forbidden by the Quran, the sacred book of Islamic religion: as early as 1850, a law was passed without any religious resistance, providing freedom for the practice of interest. ${ }^{22}$ There are other historians pointing out the support that religious men, the ulema, had given to the reform movement of the time. Instead, the traditional Ottoman socioeconomic organization and the economic mind in general was held responsible for the resistance. ${ }^{23}$

${ }^{19}$ See Kuran, Islam and Underdevelopment, p. 80.

${ }^{20}$ İbid, pp. 56-9.

${ }^{21}$ See, Buğra, Class, Culture, 1998.

${ }^{22}$ See, Mehmet Genç, "Osmanlı İmparatorluğu'nda Devlet ve Ekonomi”, V. Milletlerarası Türkiye Sosyal ve İktisat Tarih Kongresi-Tebliğler, edited by İstanbul: M.Ü. Türkiyat Araştırma ve Uygulama Merkezi.1989; and Zafer Toprak, Türkiye'de Ekonomi ve Toplum (1908-1950): Milli İktisatMilli Burjuvazi, İstanbul: Tarih Vakfı Yurt Yayınları, 1995.

${ }^{23} \mathrm{See}$, İnalcık in Kuran, Islam and Underdevelopment, p. 54; see also 
Ülgener is the only one who studied this issue within the interaction of Islamic religion and other spheres in the Ottoman Empire, by focusing on the Islamic economic ethics, including questions, such as why and how Islamic religion affected the traditional Ottoman socio-economic organization and mind. Ülgener searched for an answer to the question of how Islam could be considered an obstacle to the development of modern rational capitalism. That is why his study can also be considered a piece of economic philosophy, like Weber's study of The Spirit of Capitalism and the Protestantism Ethic. ${ }^{24}$ His theoretical guidance was apparently the Weberian framework. Agreeing the Weberian analysis of average ethic, large masses were considered "naturally" unmusical in terms of ethical and religious concerns; ${ }^{25}$ Ülgener also declared folk versions of Islam as morally nihilistic. ${ }^{26}$ Following Weber, religious principles will be turned into a mystical tradition losing the real-original meanings of these doctrinal principles. Therefore, the folk interpretation of Islam -sufi, alevi, bektaşi and rafizi versions of Islam- was responsible for its historical development in the direction of "seeing virtue in what is lacking" according to Ülgener. ${ }^{27}$ The Weberian idea that capitalism will undermine religious values in the long run also determined the theoretical orientation of Ülgener's study. Yet even today, the question of whether or not "an Islamic economy is possible," have direct political implications, has no clear answer.

\section{In What Sense an Islamic Economy Can be Talked About?}

To refer to the Weberian thesis, the cultural dimension of capitalism was basically an emancipation process from traditional religious communal ties, but putting its origin in the irrational origin of a religious belief, Protestantism as a reformed version of

Mardin, Türk Modernleşmesi, p.68; and Niyazi Berkes, Türkiye'de Çă̆daşlaşma, İstanbul: Doğu-Batı Yayınları, 1978.

${ }^{24}$ See, Weber, Protestant Ethic, 1992.

${ }^{25}$ See, Ülgener, Dünü ve Bugünü, pp. 25, 38-9, 107.

${ }^{26} \mathrm{Ibid}$, pp. 112-4.

${ }^{27}$ Ibid, pp. 25, 38-9, 80, 107. 
"traditional" Christianity, the religio/cultural aspect is still relevant in his analysis on the trasition from feudalism to the rational capitalism. ${ }^{28}$ Therefore, it can be inferred that other traditional cultures too, should have been reformed in their process of developing a rationally organised and urbanised capitalist society by ending the dominance of state and "the rural" in the socio-economic processes in general. To translate this idea into the Turkish case in the context of MÜSIAD, the significance of this Association is its middle-class avanguard nature as a role model for the newly urbanised larger population of the society. And, following Weberian formula, this thesis argues that a socio-economic system cannot truly be named as "capitalist" before the simultaneous reshaping of the cultural-moral conduct of the ordinary people in the direction of the systematization and rationalization.

Sami Zubaida ${ }^{29}$, an important follower of Weber from the Muslim world, underlined that "Economic rationality is not merely an attitute of mind, but a complex of actions which only become possible under certain social conditions." Also, he determined that Islamic religion was in peace with its relationship with the economic realm, as considering this activity as desirable and virtuous, in terms of both the doctrinal level and the historical developments of Islamic practices: According to him, there was nothing in Islam opposing to Protestantism, on the contrary they were compatible in his analysis.

Yet, this does not mean that an idea of an Islamic economy in our contemporary world can either be talked about as a ready ideal/typical formula or as a homogeneous set of Islamic practices valid all over the Muslim world. It is only in this limited and constructory framework that Nomani and Rahnema ${ }^{30}$ talk about the need to built a framework for a well-functioning Islamic economy. In doing this, preparing an "homo-Islamicus" in its ideal typical sense on the base of a new reformed Islamic ethic has crucial importance, as explored in this study in detail. Nasr ${ }^{31}$ emphasized this person "as

${ }^{28}$ See, Weber, Sosyoloji Yazlarl, p. 228.

${ }^{29}$ See, Zubaida, Economic and Political, pp. 322-3, 325.

${ }^{30} \mathrm{See}$, Farhad Nomani and A. Rahnema, Islamic Economic Systems, London, New Jersey: Zed. 1994, p. 46.

${ }^{31}$ See, Seyyed Vali Reza, "Islamic Economics: Novel Perspectives," Middle 
a conscious representative of Allah" as a necessary component of an Islamic society functioning on the principles of equality and justice. This is one of the reasons why there is no homogeneous theoretical and practical model that could easily be followed by the Islamists of the world as a whole. They seem completely aware that there is no ready formula or model of Islamic economy, and this is also what makes their search difficult in its socio-economic, cultural, as well as political dimensions:

Faced with the dilemma of solving modern economic problems by relying solely on the Shari'a, a prominent group of Iranian Shi'ite clerics has also tried to shift the focus away from a rigidly Shari'abased economic system to one in which human discretion can be afforded greater scope. (...) It is finally concluded that 'there is no such thing as a well co-ordinated policy (theory) called Islamic economics that could be applied to all times and places. ${ }^{32}$

Still, some theoretical and methodological tendencies can be determined in the writings of Islamic scholars on this topic: First of all, they are conscious that Islamic economy is an ongoing process. And second, what is important in their search for an Islamic economy is not a unique, alternative economic framework, but rather the development of a suitable economic framework functioning harmonously in an Islamic society. In this sense they originated their positions from the idea that there would be no economy that was completely value-free ${ }^{33}$. The exclusion of religious and ethical concerns from the economic realm has therefore been considered as a result of a reductionist view. This is the self-interested construction of homo-economicus of neoclassical economics. And, this formula led to a commonly shared idea that ethical and religious dimensions, taken as traditional in their very nature, are in opposition to rationality and modernity. This is the reason why they cannot talk about an Islamic economy on the same base of the neoclassical

Eastern Studies 25/4, (1989).

${ }^{32} \mathrm{See}$, Nomani and Rahnema, Islamic Economic Systems, p. 46.

${ }^{33}$ See, Syed Nawab Haider Naqvi, Islam, Economics, And Society. London, New York: Kegan Paul International. 1994; and Khurshid Ahmad, "Introduction," Studies in Islamic Economics, K. Ahmad. (ed.) Delhi: Amarprakashan. 1983. 
economics. However, Naqvi emphasized ${ }^{34}$ that considering Weberian interpretation that a normative dimension along with formal, valuefree pure economics is legitimate, it can be considered that a normative-ethical dimension has already included in all socio-cultural systems including Islam.

An equally two-sided interaction can be determined between western and eastern/Islamic worlds in this context. A strong and specific effect of the western world on MÜSIAD can be summarized in the following context:

The interaction with the West has created its impact on the MÜSIAD businessmen concerning such areas as learning and adopting the typically ideal western qualities such as rational/formal processes and mechanisms, technical and informational avanguard, work dicipline, work ethics and systematization. Since a great number of these businessmen have experiences abroad in one way or another, they have made comparative evaluations by giving concrete examples from Western countries in their description of the ideal work environment. In this framework, the work ethics and dicipline of the West form the common aspect of admiration they have verbalized. Some of the businessmen have related the subject to the religion of Islam by saying such things as, "unfortunately, it is actually the Westerners who live as our religion demands and requires in these respects. In this way, contrary to the interpretation of the Islamic religion serving the rationale of being content with the small and the limited, values and assets like the "hard" and "diciplined work" are expressed as inherent values of Islam. While the relation between the characteristics of being contestant or combatant and independent in one's thinking as required by entrepreneurship, and religiosity is thus established, some have stated that the real meaning of the "Holy War" concept lies in the understanding of piety as a continuous struggle and contest both at the individual and the societal levels. Thus, the existence of difficulties is perceived as an opportunity for the continuous and regular testing of belief and faith in the goals.

An example concerning the functioning of a house for the aged in Germany given by an enterpreneur who has previously lived in this

${ }^{34}$ See Naqvi, Islam, Economics, pp. 19-21, 130. 
country displays how the mechanisms of traditional support and solidarity can easily be abandoned: He has stated that there, a person is taken better care of than the care that is given by his very own child. ${ }^{35}$ Another example can be given by the words of one other businessman:

The milieu in Turkey does not promote or motivate work. We met a Turkish youth while dining in a Turkish restaurant in Germany. This young man was attending a professional course during the day, working at another place in the evenings and working in that restaurant during the late evening and night, and was, thus, earning his pocket money. He also asked us to hire him as our translator during the weekend. If he were in Turkey, this youth would be idly sitting in a coffee house.

In this framework, besides the ones who speak of a development in the quality of the product they produce after they had a trip abroad, there are a great number of businessmen who mention that they have gained a brand new perspective concerning production and organization, especially concerning the significance of utilizing technology. What is expressed under The Second Advancement Period Working Programme indicates that the weight given to these activities by the Association is not coincidental:

MÜSİAD, as the leader and the voice of "Anatolian Tigers" who have adopted the principle of "High Morality-Advanced Technology," has aimed at assisting the reinforcement of entrepreneurship and economic development in our country, based on free market economy, and at providing the economic growth of our industrialists and businessmen based on exports by opening out to international competition.

\footnotetext{
${ }^{35}$ See, Richard Antoun, "Sojourners Abroad: Migration for Higher Education in a Post-Peasant Muslim Society," Islam, Globalization and Postmodernity, S. A. Akbar and H. Donan, (ed.) London, New York: Routledge. 1994, p. 165: He also underlined the same points in one of his studies on the Muslim population living in Germany.
} 


\section{Conclusive Remarks}

The sum effect of all these is the transition from a formalized traditional Islamic framework to a dynamic and rationalized one. The first one is characterized by a closed and static relational setting while the second one identified with what we call modern dynamic entrepreneural atmosphere with a lot of uncertainity, risk, intellectual discussions and so on. And one interpretation of such a process will be a transition from particularistic/local ties towards a new and universally inclusive and relational and rational/meaningful synthesis. The process called "globalization" is maybe truly related to this study in this context as a "weak tie" 36 creating factor in MÜSIAD's context: ${ }^{37}$

It is observed that MÜSIAD serves the benefits of its members not only by forming a network that reaches out to all parts of Turkey but by producing "weak ties" in the international field also. The number of the members of MÜSİAD has reached to 3.000 by the year 2000. The higher rate of member numbers itself reflects this: an evidence can be included from the data from Gaziantep: there is a news that management of the Gaziantep branch put a wall album including the pictures of all Gazintep members. MÜSIAD encourages his members to do international businesses -especially in terms of technological perfection and quality.

In this framework, it is worth mentioning that the case study based on the fieldwork I conducted in $1998^{38}$ demonstrates an ideal typical business person in MÜSIAD, the man of the small town, who used to live strictly under the community control and solve his problems largely through clientelistic ties, now tries to solve his problems through new and innovative ways -by depending on his double edged economic and cultural capital of the periphery and the center. In his new life in the city, because all his problems are not economic in nature, he has to consume his cultural capital he brought

${ }^{36}$ See, Mark Granovetter, "The Strength of Weak Ties," American Journal of Sociology 78/6 (1973).

${ }^{37}$ See MǗSIAD's 1995 activities Report, 1996, p. 83.

${ }^{38}$ See, Özdemir, Religious and Socio-Economic, 2001. 
from the periphery -but, of course, he has to use this cultural capital in new and very strategic innovative ways.

The process of integration of the Turkish economy into the world capitalism is pursued in connection with the strategies developed by the businessmen of MÜSİAD. Economic and sociocultural factors mutually construct each other in that beyond just affecting each other to some degree: that reflects a specific kind of entrepreneural activity model as a historically constructed dynamic process nourished by cultural-ideological as well as socio-economic factors. Since such "traditional-informal" dimension of cultural matters is associated with tradition as Islamic identity, group cooperation and solidarity are moved to the foreground, the rather content of this process can easily be neglected. MÜSİAD's businessmen, who are conventionally seen as a part of traditional Islamic organization and/or associated with anti-modern goals/aspirations, are in fact the subject of formal and informal relations that simultaneously contain the traditional and the modern in a complex manner, like Weber's Protestant businessmen. ${ }^{39}$ Therefore, in this process we witness the re-molding of socio-cultural behavior patterns within which the business world is embedded, as a result of the pressure of new conditions.

${ }^{39}$ As known, dichotomic understandings of informal/cultural and formal/contrat-based economic relational base has recently been left recently. Beyond traditional-modern dichotomy, a simultaneous precence of them is conceptualized in both modern and traditional societies: For a source in this context, see Mark Granovetter, "Economic Action and Social Structure: The Problem of Embeddedness," American Journal of Sociology 91/3, 1985. 